\title{
Małe analizy. Etiudy w PWSFTviT
}

Images

vol. X/no. 19

Poznań 2012

ISSN 1731-450X

Poniższy tekst to fragment zapisu zajęć z reżyserii, które odbyły się 7 i 8 listopada 2007 roku.

Porząadek zajęć:

I - wstęp, umowa o przesadzonej krytyce

II - wprowadzenie narzędzi niezbędnych do analizy filmów stu-

denckich i pomocnych w pracy ze scenariuszem oraz aktorem

(spirala Zatorskiego, badanie napięć w filmie)

III - analiza filmu Rafała Skalskiego „Żeby nie było niczego”

Na początek umowa. Krytykuję z przesadą, by wyostrzyć uchybienia znalezione w Waszych filmach i tym celniej znaleźć narzędzia naprawcze. Droga ma być taka: analiza filmu (z przesadzoną krytyką), znalezienie i nazwanie defektów Waszych ostatnich dzieł, znalezienie i nazwanie narzędzi naprawczych, warsztat sprawdzający ich skuteczność.

Film Rafała każe zapytać o kilka rzeczy naraz; o kompozycję, o budowanie postaci i ról aktorskich (rola - postać w rozwoju), o odwagę wreszcie.

Zacznijmy od przedszkola, od jasnego sformułowania definicji postaci. Co to jest postać? Co to za byt szczególny? Skąd się bierze na planie naszego filmu i czego od niej oczekujemy? Czy to aktor? Czy tylko aktor?

Postać to SUMA, ucieleśniony kształt, będący wynikiem przemożnego, upartego i ukierunkowanego „mieszania krwi” DAWCY z krwią NOSICIELA. Nosiciel to aktor. Wybieramy go w zgodzie z wyobrażeniem o wyglądzie i o umiejętnościach, które posłużą postaci. To nie oznacza oczywiście konieczności wyboru wprost. Czasem lepiej przeprowadzić myśl przez postać zaprzeczającą naszym wyobrażeniom o jej fizyczności, przez postać ustawioną na tzw. kontrze. Potem, w procesie nazywanym umownie „postaciowaniem”, stopniowo nasycamy nosiciela rozmaitymi przesłankami. My, dawcy - scenarzysta, reżyser, operator, scenograf, kostiumograf, rekwizytor, charakteryzator, oraz... kultura $\mathrm{w}$ najszerszym rozumieniu. Nie, nie żartuję. Scenarzysta daje postaci zdarzenia, reżyser sposób istnienia w zdarzeniach, operator daje wyraz plastyczny, pokazuje ożywione przez proces oczy, scenograf daje kontekst, miejsce, które znacząco określa zachowanie, rekwizytor daje do ręki przedmiot, który ma ciężar, temperaturę i piętno używania, kostiumograf daje ubranie, charakteryzator modeluje, na koniec dokłada swoje promieniowanie kultura. Zaznacza się owo promieniowanie w sferach najsubtelniejszych, 
w zachowaniach oznaczających poczucie przynależności do określonego pokolenia, systemu wartości, określonego sposobu myślenia, wrażliwości i wyrażania myśli. Do kultury właśnie.

A więc mamy postać, sumę, BYT dobrze ożywiony. Dobrze to znaczy tak, żeby działał możliwie najlepiej w sprawie naszego filmu, w sprawie zaprojektowanych dla niego zdarzeń, wynikających z nich znaczeń i emocji. BYT ma tożsamość, która stale pływa między tożsamościami nosiciela i dawcy. Trzeba bardzo uważać, by to delikatne istnienie utrzymywać w równowadze, by człowiek wypożyczający postaci swój organizm, swoje serce, kości, ścięgna, mięśnie i układ nerwowy, miał zawsze otwartą drogę powrotu do swojej własnej, prywatnej tożsamości. Żeby mu się nie pomyliły światy i żeby nie obsunął się w kierunku szaleństwa. Musicie znać taktykę reżyserii, ale musicie znać przede wszystkim jej etykę. To najważniejsza wiedza.

Teraz pytanie: kto najbardziej ożywił „Golema”, kto był stwórcą w największym stopniu? Kto był najważniejszym dawcą? NIE WIADOMO. Tego - niestety - nigdy nie wiadomo. Radzę pogodzić się z tym odkryciem i odsunąć od siebie zazdrość. Bywa, że postać ożywa pod wpływem impulsu, którego nawet nie byliśmy sobie w stanie wyobrazić. Pod wpływem nagłego uderzenia wiatru, zapachu z dzieciństwa, szczekania psa lub dotknięcia włosów ukochanej osoby. Ale ten ożywczy impuls jest skutkiem, jest konsekwencją drogi, jaką przeszliśmy z aktorem. Nie zadziała sam z siebie. Nie ma takiej możliwości.

Oczywiście, reżyser ma do powiedzenia najwięcej. To on określa kształt i kierunek, w jakim rozwija się postać, a potem nadzoruje jej obecność w filmie. Niech więc ma przy tym jak najwięcej narzędzi. Przy okazji filmu Rafała chcę zapoznać Was z jednym z najważniejszych - moim zdaniem - narzędzi w procesie budowania postaci i kontrolowania jej rozwoju w filmie.

\section{SPIRALA ZATORSKIEGO, czyli najpierw myśl, potem ekspresja}

Spirala Zatorskiego jest wykładnią stawania się w dialogu, ergo - wykładnią prawdy w dialogu (w rozmowie). Stawanie się, czyli rozwój $\mathrm{w}$ dialogu, daje poczucie, że mamy oto do czynienia $\mathrm{z}$ prawdziwymi ludźmi i prawdziwą rozmową. Że najpierw jest myśl, a potem jej wyrażenie, czyli ekspresja.

Stan inny niż opisany wyżej, stan dialogowej umowności i tandety, stan dialogowego kiczu i całkowitej niewiarygodności, to stan... powszechny. Spirala Zatorskiego uzbroi was w zdolność odwracania skłonności aktorów do dialogowego fałszu, do mówienia powierzchownego i efekciarskiego.

$80 \%$ - słuchać

$10 \%$ - mieć skojarzenie (czyli w istocie - odwołać się do swojego doświadczenia, wiedzy i wyobraźni oraz zmierzyć to, co się słyszy, ze sobą) 
$5 \%$ - odpowiedzieć

$5 \%$ - nie wiedzieć, co dalej

Teraz kolejne narzędzie, które może przydać się w Waszej pracy. To narzędzie, wywiedzione wprost $\mathrm{z}$ fizyki, bada różnice potencjałów na skrajach scen. Jak zapewne pamiętacie, $\mathrm{z}$ różnicy potencjałów bierze się napięcie. Innymi słowy, by wewnątrz sceny wytworzyło się napięcie, musi powstać różnica potencjałów między jej początkiem a końcem.

Macie już uformowaną postać, macie zdolność kontrolowania jej zachowań w dialogu (spirala Zatorskiego), sprawdźcie teraz DROGĘ PRZEMIANY (drogę napięć) postaci, przeprowadzając ją przez film (przez sceny) wedle schematu:

- potencjał wejścia w scenę (kapitał wejścia)

- elektryzacja (przemiana w scenie)

- potencjał wyjścia ze sceny (kapitał wyjścia)

W nawiasach umieściłem określenia, których używam zamiennie, a które oznaczają $\mathrm{w}$ istocie to samo. Potencjał wejścia określa to, z czym postać wchodzi w scenę, z jakim kapitałem relacji z innymi postaciami. Elektryzacja określa to, co zdarza się między postaciami w scenie, jak wzajemnie na siebie oddziałują (elektryzują się), czy w ogóle coś między nimi się zdarza. Potencjał wyjścia określa naddatek, o jaki powiększa się kapitał postaci wychodzącej ze sceny. Oczywiście potencjał wyjścia postaci ze sceny poprzedniej jest jednocześnie potencjałem jej wejścia w scenę następną.

Muszę powiedzieć na marginesie, iż refleksja teoretyczna, którą się z Wami dzielę, jest moją refleksją autorską. Używam więc moich własnych, prawdopodobnie nowych dla Was (dla mnie też) określeń.

\section{Przejdźmy teraz do analizy filmu Rafała}

Początek, dzieciństwo, czas przyczyn, harcersko-oazowy krąg. Prosta na pozór opozycja: bohater nie ma poczucia przynależności do grupy, nie chce śpiewać, jest wyobcowany, więc jako dorosły dokona wyboru czegoś, co jest na przeciwnym biegunie. $Z$ buntu, $\mathrm{z}$ oporu przeciwko przymusowi. Zgadza się? Nie bardzo. Z oporu przeciwko grupie, Witek wybiera bowiem... grupę.

Oczywiście widzę inne rzeczy: zamiast krainy łagodności Witek wybiera krainę agresji, zamiast podległości wybiera dominację. Ale ta czarno-biała jednoznaczność, ta czytelność opozycji, zbyt łatwo określa świat całego filmu; oto będziemy poruszać się po wierzchu spraw, napędzani tezami o życiu jako nieustającej potrzebie kompensacji niedostatków z dzieciństwa. Te same motywacje napędzają bowiem Popowicza. Tylko marginalna postać siostry ma trochę więcej prawdy.

We wstępie do tych rozważań wspomniałem o kompozycji jako o jednym z pól słabości filmu Rafała. Teraz kilka zdań ogólniejszych. 
Kompozycja bywa niesłusznie mylona ze strukturą. Struktura to posadowienie filmu, stabilizująca go siatka, kompozycja zaś to jej dynamiczna okrywa. Ludzkie systemy kostne, ludzkie struktury są niemal identyczne. A ich okrywy? Ludzie czarni, żółci, biali, łysi, rudzi, długowłosi, niscy, wysocy, grubi, chudzi, dynamiczni, powolni... To anatomiczne porównanie najlepiej chyba ujmuje różnicę między strukturą a kompozycją. Wracam teraz do filmu Rafała, wprowadzając dwa nowe pojęcia: kompozycja pozioma i kompozycja pionowa. Kompozycja pozioma to budowanie filmu na szerokość, na rozległość, na rozprzestrzenienie, na "jak”. Kompozycja pionowa to budowanie filmu na głębokość, na intensywność, na eksplorację sensów, na „co”. Mam wrażenie, że Rafał wybrał dla swojego filmu dominację kompozycji poziomej nad pionową.

Bohater. No właśnie. Kto nim jest w filmie Rafała? W scenie kolejnej pozostajemy przy Witku. Oto Witek w trakcie manifestacji jako jej najagresywniejszy uczestnik. Jako żołnierz. Takie przedstawienie bardzo kłóci się z późniejszą próbą sformatowania Witka jako subtelnego, inteligentnego manipulatora. Tu, przy ekspozycji, przy przedstawieniu bohatera, potrzeba decyzji, kim jest. Zadymiarzem czy pociągającym za sznurki manipulatorem? Błąd. Tracę energię na poszukiwanie odpowiedzi, zamiast śledzić losy bohatera.

Kolejna scena. Wracamy do ogniska i dzieciństwa Witka. Po co? W jakiej sprawie? Rafałowi chodziło prawdopodobnie o sklejkę czasową między zadymą a tramwajem. Taki mam domysł i w trakcie filmu zużywam nań energię. Zatem wprowadzenie tej sceny jest zwyczajnym złodziejem energii. Angażuje mnie, widza, w poszukiwania, które nijak nie przydadzą się przy dalszym obcowaniu $\mathrm{z}$ filmem.

A wspomniany już tramwaj? To w nim, wraz z osobą Popowicza, pojawia się najpoważniejszy problem filmu. Jest nim oczywiście aktorska oferta pana odtwarzającego postać Popowicza. Niestety znam zachowania Kononowicza. Niestety, bo to osoba nie do podrobienia i moim zdaniem $\mathrm{z}$ próby podrabiania jej wynika jedna $\mathrm{z}$ podstawowych słabości filmu. Poza tym nie notuję rozwoju tej postaci, podobnie jak nie notuję rozwoju postaci Witka i przez cały film mam problem, który z dwóch panów jest bohaterem. Oczywiście mogę przyjąć założenie, że w żadnym z bohaterów nie dokonuje się przemiana, że o tym właśnie jest film. Ale przecież dobrze wiem, że nie o tym. Że akurat o czyś przeciwnym. O przemianie.

Zatrzymajmy się na chwilę przy motywacjach obydwu postaci. Czy dadzą się odczytać? Popowiczowi podoba się nieoczekiwana zmiana miejsc. Jego motywacja jest oczywista. A co napędza Witka? Oddanie dla idei? Nic o tym nie wiem. Potrzeba zrobienia kariery? Nikt mnie o tym nie informuje. Pieniądze? I o tym mnie nikt nie zawiadamia. Zatem jedna $\mathrm{z}$ dwóch głównych postaci porusza się po scenie zdarzeń bez dającego się odczytać napędu. Jedynym napędem jest reżyserskie nadanie. Rzeczy zdarzają się, bo tak chce reżyser. Oto 
powód, dla którego nieco lepiej grający Witek nie jest zdolny przywiązać do siebie moich emocji, zaś bardzo słabo grającemu Popowiczowi odrobinę współczuję.

Idźmy dalej. Pojawienie się Popowicza w tramwaju. A co to za figura? Zauważenie, wejście w kadr, pojawienie się w scenie to elementarne zadania, których jakość bardzo cierpi w studenckich filmach. Zatrzymajmy się na chwilę przy takiej „błahostce” jak zauważenie. Co w nim można zanotować? Zauważenie jest jednym $\mathrm{z}$ podstawowych zdarzeń filmowych - od początku istnienia kina zauważenie, w zależności od tego, jak je zrealizujemy, może dać napęd następnym zdarzeniom, a także wiedzę o wzajemnych stosunkach zauważających się osób. Zauważenie jest „otwarciem drzwi” do następnych scen. Dlatego musi być zrealizowane bezbłędnie i być niebudzącą wątpliwości wykładnią intencji autora filmu. W zauważeniu da się odczytać cały dramaturgiczny mikroświat (moment zauważenia, narodziny nowych emocji w związku z zauważeniem, temat zauważenia, „cena” emocjonalna, powrót do działań sprzed zauważenia $\mathrm{z}$ „naddatkiem” wynikłym z zauważenia).

Co mamy w filmie Rafała? Oto Popowicz, odsłonięty przez jakiegoś pasażera, formułuje pretensje wobec kanara, że ten nie sprawdza Witka. Dopiero słowa Popowicza naprowadzają mnie na temat sceny. Zanim padną, jestem bezradny. Nie wiem, o co chodzi. Tracę energię. Więc - złodziej energii? Oczywiście, Popowicz może pojawić się w filmie zdawkowo, niejako przy okazji. Niech jednak widz zna sytuację. Ja nie dostrzegam, że kanar omija Witka. Dobre, nasycone jest spojrzenie Witka na Popowicza. To spojrzenie rodzi napięcie. Po co więc Witek odwraca głowę?

Kolejna scena. Nagrywanie wypowiedzi. Popowicz naiwny i dziecinny. Zupełnie niewiarygodny. Odkrywam Witka jako manipulatora. Kim więc był wcześniej? Po drodze drobny błąd warsztatowy. W montażu kontynuacji rozmówcy nie patrzą na siebie, a wystarczyłoby trochę później uciąć portret Popowicza.

Błąd kierunków w scenie z telewizorami. Też drobny, ale dokuczliwy. Można go było ominąć, ustawiając Popowicza w dwójkowym portrecie $\mathrm{z}$ Witkiem $\mathrm{z}$ lewej strony i fałszując nieco ustawienie do $3 / 4$, tak by Witek patrzył (P-L). W ujęciu następnym, po podwójnym portrecie, Witek nie kontynuuje ekspresji. Można je było uciąć kilka klatek później i byłoby OK. To są błędy drobne, ale widoczne na tle aktorskiej mizerii obydwu panów.

Teraz w filmie następuje dalszy ciąg wizerunkowej „obróbki” Popowicza. Notuję to samo naiwne, dziecinne i wyzute $z$ charyzmy zachowanie aktora. Jeżeli to reżyserski zamysł, to chciałbym go zrozumieć. Dlaczego Witek wybrał kretyna? Co w nim zobaczył? Czy kretyn porywa tłumy? Skąd mam to wiedzieć? Widzę też niezrozumiałe zachowanie Witka. Oto odchodzi nagle i zatrzymuje się tyłem. Co się stało? Co da się odczytać z jego zachowania? Dlaczego reżyser skąpi mi oczu bohatera? 
Zdarzenie na dworcu. Naiwne. Za wywiad z takim kandydatem nikt nie dałby grosza. Żart z „kaczorem” w złym guście.

Zróbmy teraz trochę większy krok do przodu. Witek i Popowicz jadą w kampanijną trasę. W samochodzie następuje rozmowa o kandydowaniu na urząd prezydenta. Jaki to zdarzenie ma poziom? Żenująco niewiarygodny. Jakie ta scena ma przygotowanie, jakie przesłanki wiarygodności? Żadne. To jest sytuacja z kategorii: „, a małemu Franiowi się zdaje..., że tak wygląda kreowanie postaci i zdarzeń politycznych”. To zdarzenie urąga inteligencji najprostszego widza. Jest życzeniowe i nierozumne.

Dyskoteka. Kim tym razem jest Witek? DJ-em czy bokserskim anonserem? Nic w jego zachowaniu nie jest konsekwencją tego, o czym już wiemy. W zachowaniu aktorskim królują minoderia i... miny. Nic z tego nie rozumiem. Rola Witka jest zatomizowana, rządzi nią przypadek, nie objawia się jako skutek świadomego, dającego się obserwować procesu. Rola to przecież suma, to dodające się do siebie zachowania aktorskie, które powinny być tak zakomponowane, by ułożyły się w całość.

Teraz w filmie następuje najmniej zrozumiałe pęknięcie. Oto na naszych oczach, nie wiadomo z jakiego powodu (z reżyserskiego nadania), Popowicz zyskuje poklask tłumu. Obserwujemy narodziny nagłej zazdrości. Witek przeżywa tandetny dramat. Tłum woli Popowicza! A z jakiego powodu, jeżeli wolno zapytać? Co takiego się stało? Gdzie przyczyny narodzin tego aplauzu? W głowie reżysera. Reżyser po prostu tak chciał. To się stało $\mathrm{z}$ reżyserskiego nadania. Podobnie dzieje się z Witkową zazdrością. Też jest nadana, niejako - zadedykowana nam. Witek zazdrosny o idiotę, o karykaturę? Niedorzeczne.

Wreszcie zepchnięcie Popowicza w tłum, wymiana spojrzeń z Witkiem pozującym na dyskotekowego demiurga i ugodzenie nożem. Dobra, dość wiarygodna scena, choć nie rozumiem tej próby sił między „stwórcą” a „stworzeniem”. O co idzie walka, o co toczy się gra? Nie przedstawiono mi stawki, więc nie czuję napięcia.

Szpital. Tu sprawy mają się źle. Kompletnie nie czuję tematu wywiadu. Czy Witek kontynuuje kampanię, czy naprawdę współczuje Popowiczowi? Domyślam się, że współczuje, bo to odrobinę tłumaczy jego zachowanie w windzie. Odrobinę. Poza tym nie ma w całym, powtarzam, całym filmie materiału na taką reakcję. Nie uzbierało się - ani naraz, ani po troszeczku. Podobnie jest z życzeniowym i nieczytelnym zachowaniem siostry Popowicza. Wymawia lojalność za pomocą kurtki? A może chce, żeby Witek nie marzł?

Kilka zdań na koniec. Rafał zdecydował się nadać swojemu filmowi fakturę dokumentu. Temu służą dość dobrze wszystkie chropowatości. Film naśladuje opowiadanie dokumentalne dość udatnie. Tylko że za rozedrganą, wysoko kontrastową, wyzutą ze szczegółów fotografią powinna pójść „dokumentalność” zachowań aktorskich. $\mathrm{Z}$ tym, niestety, jest poważna bieda. Cierpi też scenariusz, a z nim 
słabo narysowani i skrajnie nie umotywowani bohaterowie. Wiemy z życia, jak wygląda świat polityki. Wiemy, ile w nim drapieżności i rozpulsowania. Film Rafała zatrzymuje się w połowie drogi. Chociaż udaje dokument, jest dużo bardziej gładki niż życie. To dlatego na wstępie do analizy użyłem pytania o odwagę.

\section{WARSZTAT - MOTYWACJE, RELACJE, PRZEMIANA \\ (potencjał wejścia w scenę, elektryzacja, potencjał wyjścia ze sceny)}

Jako zadanie warsztatowe zalecam Rafałowi przebudowanie, pogłębienie i powtórną realizację sceny, w której Popowicz w asyście Witka udziela wypowiedzi (przemawia) do kamery. Cel jest taki, by w przebudowanej scenie ulokować narodziny prawdziwej, głębokiej motywacji Popowicza. Aby określić rodzaj relacji między Witkiem a „wytworem” jego inteligencji i sprytu. Aby dać Popowiczowi szansę na odkrycie nowej, nieznanej mu dotąd, ciemnej strony jego natury.

\section{SCENA}

Popowicz stojący na tle emblematu Narodowej Akcji Odrodzenia przemawia. Tekst taki jak w filmie aż do momentu:

POPOWICZ: Nie ma tego w kartkach...

Witek podchodzi. Patrzy Popowiczowi w oczy. W powietrzu zawisa napięcie. Witek odzywa się:

WITEK: Uderz mnie.

POPOWICZ: Co?!...

W: Nic. Uderz mnie.

P: Ale za co?

W: Za nic. Po prostu uderz.

Popowicz nie może uwierzyć.

P: Ale Witek, ja...

Przerywa, bo oto Witek błyskawicznie uderza go otwartą dłonią w twarz. Z nosa Popowicza zaczyna cieknąć krew. Mężczyzna wyciera ją wierzchem dłoni. Jest przerażony i zdezorientowany. Podnosi spojrzenie na prześladowcę. Witek podaje mu chusteczkę.

W: No i co? Uderz mnie. Czekam.

P: Nie uderzę pana. Nie chcę... nie... potrafię.

Witek znów wymierza Popowiczowi soczysty policzek.

W: Potrafisz.

P: Nie...

Przerywa, bo oto Witek po raz kolejny zamierza się dłonią. Popowicz kuli się, ale Witek nie uderza. Zatrzymuje dłoń w połowie drogi. Uśmiecha się, potem jeszcze raz udaje, że chce uderzyć. Twarz Popo- 
wicza rozjaśnia się. Podejmuje grę. Teraz on udaje, że chce uderzyć, a Witek udaje, że unika ciosu. Za którymś razem Popowicz uderza naprawdę. Mocno. Nieruchomieją obydwaj. Witek podaje kartkę. Zwraca się do Popowicza.

\section{W: Czytaj.}

Rozlega się dźwięk włączanej kamery i w chwilę po nim, brzmiący już zupełnie inaczej, głos Popowicza. 